\title{
Effectiveness of delivery methods in the transfer of soft skills
}

\section{Monique Keevy}

Department of Accountancy, University of Johannesburg, South Africa.

\begin{abstract}
Accounting education has in recent years increasingly emphasised the need for developing soft skills. To this end, various delivery methods have been advocated other than the conventional lecture format during the academic programme. This paper reports on a study of the perceptions of graduates on the effectiveness of delivery methods during the academic programme in transferring soft skills. A questionnaire with open and closed-ended questions was administered. Graduates reported that soft skills were most effectively developed when using case studies, followed by collaborative learning. Surprisingly, graduates also indicated lectures as an effective method in soft skills development, by ranking this method after collaborative learning. However, the method of computer-based activities, was reported as the least effective method in developing soft skills. This is a concern, given the prevalence and use of computers and technology in the accounting profession. Educators need to do more in inculcating soft skills, by using additional methods such as mentorship programmes and self-assessment.
\end{abstract}

Keywords: Academic programme, accountants, pervasive skills, soft skills, teaching methods, higher education. 


\section{Introduction}

This paper reports on a study of the perceptions of accounting graduates ${ }^{1}$ on the effectiveness of pedagogical methods used in the transfer of soft skills during the academic programme. Soft skills are also referred to as pervasive skills, transferable skills, non-technical skills, social and interpersonal skills, generic skills or employability skills in the accounting literature (Boyce, Kelly, Williams \& Yee, 2001; Ballantine \& McCourt Larres, 2009; Watty, Jackling \& Wilson, 2014; SAICA, 2017). These skills are not subject- or domain-specific (Boyce et al., 2001; Ballantine \& McCourt Larres, 2009), unlike technical skills which become obsolete and "often not transferable across different jobs" (Kavanagh \& Drennan, 2008, p. 282).

Since the 1980s there have been concerns from accounting educators and professional bodies internationally as to the relevancy of accounting academic programmes. Several reports (American Accounting Association (AAA), 1986; AAA, 1989; Accounting Education Change Commission (AECC), 1990) expressed the need for accounting graduates to master both technical and soft skills. The change in accounting education stemmed from factors such as globalisation, corporate scandals, increased regulations and evolving technologies on business activities (Albrecht \& Sack, 2000). In the words of Lines and Gammie (2004) “... the business world in which accountants operate, is becoming ever more dynamic and information rich. The skills and competencies that were appropriate only a generation ago are now far less" (p. 2).

Consequently, professional accounting bodies and educators developed frameworks and reports to address the changes in the profession; and to provide guidance on ways to develop soft skills (Albrecht \& Sack, 2000; Lines \& Gammie, 2004; Pathways Commission, 2012). In line with other accounting bodies, and the requirements of the International Federation of Accountants (IFAC) the South African Institute of Chartered Accountants (SAICA) developed a Competency Framework (CF), which specifies the technical, and most notably, the soft skills that aspirant chartered accountants (CAs) should acquire during qualification (SAICA, 2017). The CF groups the soft skills into three categories, namely, "ethical behaviour and professionalism" (IA), "personal attributes" (IB) and "professional skills" (IC). These categories are further sub-divided into 26 skills, including eight skills in the IA category, ten skills in the IB category and eight skills in the IC category.

Various educators have responded to the calls by the accounting profession by introducing bespoke methods to address the teaching of soft skills. However, few studies acknowledge the views and reflections of graduates after the academic programme. Lines and Gammie

\footnotetext{
${ }^{1} \mathrm{~A}$ graduate in the context of this study is considered an aspirant chartered accountant (CA) who has completed his/her university academic programme and is in the process of completing his/her training programme.
} 
(2004) convey that students play an integral part in the learning process, while Viviers, Fouché and Reitsma (2016) suggest that educators should communicate the methods used to inculcate skills to their students. Therefore, the present study examines the perceptions of graduates on the effectiveness of the methods used during the academic programme in developing soft skills.

The present study contributes to the literature in several ways. First, the paper provides the effectiveness of certain methods in developing soft skills. As emphasised by de Villiers (2010), "despite an already full degree programmes and other internal challenges, faculty will need to find innovative ways to deliver on the demand of stakeholders if they wish to remain relevant and competitive as providers of choice" (p. 10). Given the emphasis of soft skills in the accounting curriculum, the aim of this paper is to understand which methods contribute most to their development. Moreover, accounting schools are under pressure to provide soft skills to graduates entering the profession (de Villiers, 2010). Consequently, educators in South Africa are not alone in their challenge of equipping graduates with the soft skills. Therefore, this study is also useful internationally, on methods that graduates found effective during their academic programme.

\section{Literature review}

The traditional method of merely lecturing to transfer knowledge is not effective in developing soft skills (Sawyer, Tomlinson \& Maples, 2000; IFAC 2015). Bonk and Smith (1998) reiterate this view by conveying that lectures have a narrow focus of knowledge acquisition, where the educator is the source of knowledge. Objective tests have been described as another passive method used in accounting pedagogy that does not result in the transfer of soft skills (AECC, 1995). The increasing technical content required of the accounting curriculum means educators continue to rely on these passive teaching techniques (Boyce et al., 2001). Moreover, an increasing body of work argues for practical, real-world scenarios to be used when teaching soft skills (Mohamed \& Lashine, 2003; de Villiers, 2010; Keevy, 2016a). For example, Moilanen (2017, p. 194) argues that "using assignments with real world cases with more ambiguous situations with incomplete information in teaching has offered a way to promote learning skills". This ensures that educators adopt "a creative learning process that does not depend on memorization and extensive use of textbooks" but rather one that is "based on team work, assign[s] students to real companies, case studies, oral presentations, team teaching, involving business professionals in the class rooms, and use of technology and accounting packages" (Mohamed \& Lashine, 2003, p. 9).

Consequently, there is general consensus that teaching methods must change (AAA, 1986; 1989; Lines \& Gammie, 2004). It has been suggested that a combination of teacher-centred (passive teaching) and student-centred (active teaching) methods should be used (Adler \& 
Milne, 1995; Mohammed \& Abdullah, 2018). Jointly, these methods produce well-rounded accounting graduates with a strong technical foundation as well as additional skills to aid their long-term career success (Mohammed \& Abdullah, 2018).

Various educators have responded to the calls by the accounting profession by introducing bespoke "active" methods to address the teaching of soft skills in accounting curricula. For example, Adler and Milne (1995) used a group exercise with the following components: a case study, seminar, presentation, critique session, class discussion and feedback session. A group of students took the lead by presenting a case study and facilitating a seminar discussion. Another group of students then critiqued the case study. Lecturers facilitated the class discussion and feedback session. Cases therefore provide the platform for promoting interaction and discussion of ideas through collaboration (AECC, 1995; Boyce et al. 2001). Cases also provide students with a connection to the real world by engaging in problemsolving, critical thinking and communicating to deal with complex issues (AECC, 1995; Fortin \& Legault, 2010; IFAC, 2015). Case studies, in conjunction with collaborative learning can provide an ideal platform to develop soft skills (Boyce et al., 2001; Samkin \& Keevy, 2019). Collaborative learning has been described as one of the best learning resources insofar as it permits interaction between students who work in groups with a shared responsibility for the final outcome (Boyce et al., 2001). The evidence suggests that students engaging in collaborative learning achieve higher grades and develop soft skills better than their counterparts who opt for lecture-based learning (Fortin \& Legault, 2010).

The use of mentorship programmes has also been described as a student-centred approach, given that students are no longer seen as "an empty vessel to be filled by the instructor" (Spanier, 2001, p. 110). By fulfilling a mentorship role, educators have a far greater educational impact on students by not restricting them to the classroom environment (Spanier, 2001). Jackling and McDowall (2008) convey that mentoring programmes have "the potential to assist in addressing not only academic issues but also more indirectly the social issues that underpin the totality of the university experience" (p. 449).

In a few South African studies, it was found that case studies (Keevy, 2016a), collaborative learning exercises (Keevy, 2015), and mentorship programmes (Keevy, 2016b) could be used to develop all of SAICA's soft skills. However, it was reported that academics did not readily use these methods during the academic programme to inculcate soft skills, as only $64 \%$ of academics used case studies, $37 \%$ used collaborative learning exercises and only $18 \%$ used mentorship programmes.

\section{Research method}

In order to explore graduates' views as to the effectiveness of methods in developing soft skills during the academic programme, a research instrument in the form of a web-based 
questionnaire was developed to elicit the necessary information. The questionnaire consisted of five sections. The first section attempted to elicit information on the university where the participants' completed their academic programme as well as their current training programme. The remaining four sections consisted of closed-ended, ranking questions of a quantitative nature. Participants were asked to rank the effectiveness of the methods used during the academic programme contributing to their soft skills development. The ranking was from 1 (most important) to 8 (least important), and participants could use each number only once. Open-ended questions were also included in the questionnaire to support findings from the questions relying on the ranking response.

The web-link on the questionnaire contained a sidebar guiding participants on the skills included within each of the three categories when answering the questions. For example, when answering the questions for a particular pervasive skill category, a sidebar appeared containing the list of the different skills under each category (see Table 1). The questionnaire was pilot tested by a selected group of students and graduates. A data controller was used to set up an online website where the questionnaire could be answered and the data recorded. The questionnaire, containing a dedicated uniform reference (URL), was sent via email to graduates. The participants were directed to a website and asked to complete the questionnaire by clicking on the URL. The data controller collated the completed questionnaires electronically.

Table 1. List of individual skills included in the IA, IB and IC categories of SAICA's soft skills.

IA Uses an ethical reasoning process, protects the public interest, acts competently with honesty and integrity, performs work competently and with due care, maintains objectivity and independence, avoids conflict of interest, protects the confidentiality of information, maintains and enhances the profession, and adheres to laws, professional standards and policies.

IB Self-manages, demonstrates responsible leadership, maintains and demonstrates competence and recognises limits, strives to add value in an innovative manner, manages change, treats others in a professional manner, is a life-long learner, plans and effectively manages teams and projects, works effectively as a team member, manages time effectively, and demonstrates good corporate citizen attributes.

IC Obtains information, thinks critically, solves problems and makes decisions, communicates effectively and efficiently, manages and supervises, understands and uses appropriate IT systems and tools, considers and applies legal concepts, and understands how the national and international environment impacts a CAs role.

$$
\text { Source, SAICA (2017). }
$$

$\mathrm{IA}=$ ethical behaviour and professionalism, IB = personal attributes, $\mathrm{IC}=$ professional skills. 


\subsection{Population and response rate}

The population for the empirical work included all graduates who wrote the Assessment of Professional Competence (hereafter APC). In total, 2050 emails were dispatched with a response rate of $66 \%$. The questionnaire in its entirety was part of a bigger data set. Therefore, only $34 \%$ of respondents addressed the portion of the questionnaire relevant to this paper, as none of the questions in the questionnaire was compulsory. As the APC is the final assessment to qualifying as a CA, the graduates had already undergone the full scope of the academic programme and would have had first-hand knowledge of methods used during the academic programme (SAICA, 2017).

\section{Empirical findings}

\subsection{Graduates' views on the effectiveness of the delivery methods in developing soft skills}

The objective of these four sections in the questionnaire was to elicit graduates' views on which academic programme methods developed soft skills most effectively from an overall perspective; and in terms of the IA, IB and IC category of soft skills. The results are set out in Table 2 below, and are presented from the most effective to the least effective, based on the mean.

Table 2. Graduates' views on the effectiveness of methods in developing soft skills.

\begin{tabular}{|c|c|c|c|c|c|c|c|c|c|c|c|c|}
\hline \multirow{2}{*}{$\begin{array}{l}\begin{array}{l}\text { Effectiveness of } \\
\text { methods in } \\
\text { developing soft } \\
\text { skills }\end{array} \\
\text { Methods }\end{array}$} & \multicolumn{3}{|c|}{$\begin{array}{c}\text { Section } 2 \\
\text { Overall: Soft skills }\end{array}$} & \multicolumn{3}{|c|}{$\begin{array}{c}\text { Section } 3 \\
\text { IA: Ethical } \\
\text { behaviour \& } \\
\text { professionalism }\end{array}$} & \multicolumn{3}{|c|}{$\begin{array}{c}\text { Section } 4 \\
\text { IB: Personal } \\
\text { attributes }\end{array}$} & \multicolumn{3}{|c|}{$\begin{array}{c}\text { Section } 5 \\
\text { IC: Professional } \\
\text { skills }\end{array}$} \\
\hline & $\mathbf{M}$ & $\mathbf{R}$ & $\mathbf{n}$ & $\mathbf{M}$ & $\mathbf{R}$ & $\mathbf{n}$ & $\mathbf{M}$ & $\mathbf{R}$ & $\mathrm{n}$ & $\mathbf{M}$ & $\mathbf{R}$ & $\mathbf{n}$ \\
\hline Case studies & 2.61 & 1 & 687 & 2.88 & 1 & 579 & 3.15 & 1 & 578 & 2.71 & 1 & 578 \\
\hline $\begin{array}{l}\text { Collaborative } \\
\text { learning }\end{array}$ & 3.66 & 2 & 685 & 3.70 & 2 & 579 & 3.39 & 2 & 579 & 3.73 & 2 & 577 \\
\hline Lectures & 3.95 & 3 & 685 & 3.95 & 3 & 576 & 4.45 & 4 & 575 & 4.28 & 3 & 576 \\
\hline Objective tests & 4.41 & 4 & 684 & 4.49 & 4 & 576 & 4.58 & 5 & 574 & 4.34 & 5 & 575 \\
\hline Self-assessment & 4.48 & 5 & 684 & 4.54 & 5 & 576 & 4.11 & 3 & 576 & 4.30 & 4 & 578 \\
\hline $\begin{array}{l}\text { Mentorship } \\
\text { programmes }\end{array}$ & 5.41 & 6 & 680 & 5.03 & 6 & 574 & 5.14 & 6 & 574 & 5.44 & 7 & 575 \\
\hline $\begin{array}{l}\text { Orals and } \\
\text { presentations }\end{array}$ & 5.50 & 7 & 682 & 5.51 & 7 & 574 & 5.25 & 7 & 574 & 5.39 & 6 & 574 \\
\hline $\begin{array}{l}\text { Computer-based } \\
\text { activities }\end{array}$ & 5.76 & 8 & 680 & 5.83 & 8 & 576 & 5.82 & 8 & 572 & 5.69 & 8 & 574 \\
\hline
\end{tabular}

$\mathrm{n}=$ number of respondents who answered the question; $\mathrm{M}=$ Mean; $\mathrm{R}=$ ranking of $1-8$ based on the Mean score. 
Interestingly for the soft skills as a whole and for all three categories of soft skills, case studies were ranked in the first position, collaborative learning in second position and computerbased activities in the last position by graduates. As far back as 1990, the AECC communicated that using technology creatively in the classroom is essential. Added to this, given the technological advancements in business, it is imperative that accounting teaching focuses on blended learning opportunities to transfer soft skills (de Villiers, 2010). Therefore, it is a concern that graduates ranked computer-based activities in the last position. Participants, however, noted that educators should provide computer-based activities through online lectures (participant 436), interactive e-learning (participant 190), and online quizzes and assignments (participant 764). Lastly, one participant stated that:

Information technology should have played a bigger role in the syllabus and should have continued into 3rd year level of studies (participant 358).

What is also surprising is that lectures were ranked in either third or fourth position by graduates, and that objective tests was ranked in fourth or five position by graduates. From this result, the assumption that can be made is that these methods are readily used by educators and therefore, considered as effective methods by graduates. However, these methods used individually merely result in knowledge transfer (AECC, 1995; Sawyer, et al., 2000; IFAC 2015). Graduates conveyed in comments that educators should use more interactive lectures (participant 1051), and video lecturing as a means to support the academic programme (participants 1273, 1346).

\section{Conclusions, limitations and areas for future research}

This paper reports on a study of the perceptions of accounting graduates on the effectiveness of teaching methods in the transfer of soft skills during the academic programme. The results found that case studies followed closely behind collaborative learning as the most effective methods in developing soft skills. Educators are encouraged to rely less on lecturing and objective tests, but introduce bespoke methods, where students can be active participants in the learning process. The results also found that graduates viewed computer-based activities as the least effective method in inculcating soft skills. Therefore, the reason for this low ranking should be researched further, given the prevalence and increasing use of technology in business.

A limitation of this study was that graduates were asked to rank the various methods. It is not clear from the results whether these methods are in fact being utilised by educators. Furthermore, certain methods could be used jointly during the academic programme. For example, computer-based activities in the form of an Excel spreadsheet could be used in a case study exercise. However, this is not apparent from the questionnaire, which could have resulted in confusion among participants when ranking the methods. Further research could 
build on this study by using more interpretive approaches such as questionnaires or focus groups to gather information on how these methods are being utilised during the academic programme. A further limitation of this study is that there are various methods that can be used during the academic programme, such as role plays, peer assessment and the like. The given study merely focused on eight methods, six of which are active methods and two passive methods to obtain graduates views. Therefore, further research could build on this study by obtaining insight into all relevant pedagogical methods.

\section{References}

Accounting Education Change Commission (AECC) (1990). Position and issues statements of the Accounting Education Change Commission. Available: http://aaahq.org/AECC/pdf/position/pos1.pdf (accessed: 18 August 2011).

Accounting Education Change Commission (AECC). (1995). Intentional Learning: A Process for Learning to Learn in the Accounting Curriculum. Sarasota, Florida: Accounting Education Change Commission and American Accounting Association.

Adler, R.W., \& Milne, M.J. (1995). Increasing learner-control and reflection: towards learning-to-learn in an undergraduate management accounting course. Accounting Education: An International Journal, 4(2), 105-119.

Albrecht, W., \& Sack, R. (2000). Accounting education: Charting the course through a perilous future. American Accounting Association: Sarasota, FL.

American Accounting Association (AAA) (1986). The Bedford Report, Future accounting education: Preparing for the expanding profession. Available: https://aaahq.org/AECC/future/index.htm (accessed 31 May 2013).

American Accounting Association (AAA) (1989). Perspectives on Education: Capabilities for success in the accounting profession. Available: https://aaahq.org/AECC/big8/cover.htm (accessed 31 May 2013).

Ballantine, J., \& McCourt Larres, P. (2009). Accounting undergraduates' perceptions of cooperative learning as a model for enhancing interpersonal and communication skills to interface successfully with professional accountancy education and training. Accounting Education: An International Journal, 16(4), 387-402. doi: 10.1080/09639280902719366.

Bonk, J.C., \& Smith, G.S. (1998). Alternative instructional strategies for creative and critical thinking in the accounting curriculum. Journal of Accounting Education, 16(2), 261-293. doi: 10.1016/S0748-5751(98)00012-8.

Boyce, G., Kelly, A., Williams, S., \& Yee, H. (2001). Fostering deep and elaborative learning and generic (soft) skill development: the strategic use of case studies in accounting education. Accounting Education: An International Journal, 10(1), 37-60. doi: $10.1080 / 09639280121889$.

de Villiers, R. (2010). The incorporation of soft skills into accounting curricula: preparing accounting graduates for their unpredictable futures. Meditari Accountancy Research, 18(2), 1-22. doi: 10.1108/10222529201000007. 
Fortin, A., \& Legault, M. (2010). Development of generic competencies: Impact of a mixed teaching approach on students' perceptions. Accounting Education: An International Journal, 19(1-2), 93-122. doi: 10.1080/09639280902888195.

International Federation of Accountants (IFAC). (2015). Handbook of International Education Pronouncements, viewed: 26 October 2016, from http://www.ifac.org/system/files/publications/files/IAESB-2015-Handbook_0.pdf.

Jackling, B., \& McDowall, T. (2008). Peer mentoring in an Accounting setting: A case study of mentor skill development. Accounting Education: An International Journal, 17(4), 447-462. doi: 10.1080/09639280802436756.

Kavanagh, M.H., \& Drennan, L. (2008). What skills and attributes does an accounting graduate need? Evidence from student perceptions and employer expectations. Accounting and Finance, 348, 279-300. doi: 10.1111/j.1467-629X.2007.00245.x.

Keevy, M. (2016). Using case studies to transfer soft skills (also known as pervasive skills): Empirical evidence. Meditari Accountancy Research, 24(3), 458-474. doi: 10.1108/MEDAR-04-2015-0021.

Keevy, M. (2016b). Using mentorship programmes to transfer pervasive skills (soft skills): Empirical evidence. GAI International Academic Conferences Proceedings 2016 Prague International Academic Conference, September 4-7, 2016 Prague, Czech Republic.

Keevy, M. (2015). Using collaborative learning exercises to transfer pervasive skills: Some South Africa evidence. Journal of Economic and Financial Sciences, 8(2), 456-473.

Lines, D., \& Gammie, E. (2004). Assessment methods report to the education committee of the International Federation of Accountants. Robert Gordon University: Aberdeen, Scotland.

Mohamed, E.K.A., \& Lashine, S.H. (2003). Accounting knowledge and skills and the challenges of a global business environment. Managerial Finance, 29(7), 3-6. doi: 10.1108/03074350310768319.

Mohammed, N.F., \& Abdullah, A. (2018). Student-centered pedagogy: from the perspective of professional accounting education. Proceedings of the $3^{\text {rd }}$ UUM International Qualitative Research Conference, Melaka, Malaysia, 10-12 July.

Moilanen, S. (2017). The context-specific conceptions of learning in case-based accounting assignments, students' characteristics and performance. Accounting Education: An International Journal, 26(3), 191-212. doi: 10.1080/09639284.2016.1274915.

Pathways Commission. (2012). Charting a national strategy for the next generations of accountants. AAA: Sarasota, FL \& AICPA: New York, NY.

Sawyer, A.J., Tomlinson, S.R., \& Maples, A.J. (2000). Developing essential skills through case study scenarios. Journal of Accounting Education, 18, 257-282. doi: 10.1016/S07485751(00)00019-1.

South African Institute of Chartered Accountants (SAICA). (2017). Competency Framework Detailed Guidance for the Academic Programme, viewed: 6 March 2018, from: https://www.saica.co.za/Portals/0/LearnersStudents/documents/Competency\%20Frame work\%202019.pdf. 
Samkin, G., \& Keevy, M. (2019). Using a stakeholder developed case study to develop soft skills. Meditari Accountancy Research, 27(6), 862-882. doi: 10.1108/MEDAR-01-20180260.

Spanier, G.B. (2001). Beyond teaching to mentoring. Edited by Reinarz, A.G. and White, E.R. San Francisco, California: Jossey-Bass Inc.

Viviers, H.A., Fouché, J.P., \& Reitsma, G.M. (2016). Developing soft skills (also known as pervasive skills): Usefulness of an educational game. Meditari Accountancy Research, 24(3), 368-389. doi: 10.1108/MEDAR-07-2015-0045.

Watty, K., Jackling, B., \& Wilson, R.M.S. (2014). Personal transferable skills in accounting education. Routledge Taylor \& Francis Group: London \& New York. 